\title{
Anomalous origin of circumflex coronary artery from right pulmonary artery in a hypoplastic left heart syndrome child
}

\author{
Radoslaw Jaworski ${ }^{1}$, Andrzej Kansy ${ }^{2}$, Przemysław Łaniewski-Wołłk ${ }^{3}$ \\ ${ }^{1}$ Cardiac Surgery Department, Pomerian Center of Traumatology, Gdansk \\ ${ }^{2}$ Cardiac Surgery Department, The Children's Memorial Health Institute, Warsaw \\ ${ }^{3}$ Department of Anaesthesiology and Intensive Care, The Children's Memorial Health Institute, Warsaw
}

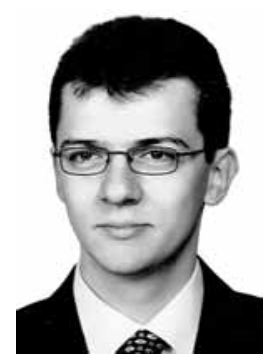

Kardiochirurgia i Torakochirurgia Polska 2014; 11 (2): 210-212

\begin{abstract}
We describe the case of a newborn with hypoplastic left heart syndrome (HLHS) and aberrant origin of the circumflex coronary artery from the right pulmonary artery. The patient underwent a modified Norwood procedure with direct reimplantation of the circumflex coronary artery to the neo-aorta, but died on the $5^{\text {th }}$ postoperative day because of myocardial failure. Detailed assessment of coronary arteries as part of the routine echocardiographic evaluation of HLHS and intraoperative inspection of them is crucial.

Key words: hypoplastic left heart syndrome, coronary artery anomaly, congenital heart disease.
\end{abstract}

\section{Introduction}

The anomalous origins of coronary arteries in children with hypoplastic left heart syndrome (HLHS) have been described in the literature. This concerns mainly the left coronary artery arising from the pulmonary artery [1]. There are only a few descriptions of coronary arteries originating from the right pulmonary artery. Such anomalies are always a challenge during surgical procedures mainly because they are diagnosed in the operation room, and the postoperative course of operated children is very doubtful. That is why the majority of these anomalies are maintained by many authors to be lethal.

\section{Case report}

A female term infant (body weight 3480 g) was admitted to the Department of Cardiothoracic Surgery, Children's Memorial Health Institute in Warsaw on the first day of life in good condition (Apgar 10) with suspicion of HLHS on prostaglandin E continuous infusion $(0.02 \mu \mathrm{g} / \mathrm{kg} / \mathrm{min})$. Metabolic acidosis was present. On echocardiographic evaluation there was right atrial enlargement with nonre-

\section{Streszczenie}

W pracy opisano przypadek kliniczny noworodka z zespołem hipoplazji lewego serca i nieprawidłowym odejściem gałęzi okalającej lewej tętnicy wieńcowej od prawej tętnicy płucnej. U dziecka wykonano operację Norwooda w modyfikacji Sano z przeszczepieniem gałęzi okalającej lewej tętnicy wieńcowej do neoaorty. W 5. dobie pooperacyjnej dziewczynka zmarła z powodu niewydolności serca. Dokładna ocena przebiegu tętnic wieńcowych $u$ dzieci z zespołem hipoplazji lewego serca jest w planowaniu zabiegu operacyjnego niezwykle istotna.

Słowa kluczowe: zespół hipoplazji lewego serca, anomalie tętnic wieńcowych, wrodzona wada serca.

strictive atrial septal defect, aortic valve stenosis (diameter of $4.2 \mathrm{~mm}$ ) and mitral valve stenosis (diameter of $6.7 \mathrm{~mm}$ ), a small left ventricle, diminutive ascending aorta, left vena cava superior and decreased cardiac function. The duct was large and widely open. The patient was referred for a first stage palliative operation of HLHS. On day 14 of life the Norwood operation in Sano modification was performed. After standard median sternotomy, chest opening and thymus removal the pericardium was opened. Cardiopulmonary bypass was instituted with cannulation of the innominate artery and single venous cannulation of the right atrium. After pulmonary arteries were snared the child was cooled down to $16^{\circ} \mathrm{C}$ core temperature and circulatory arrest was commenced. On dissection of the right pulmonary artery (RPA) an aberrant vessel of about $1 \mathrm{~mm}$ in diameter arising from its distal part was discovered. There were the right coronary artery and left coronary artery arising from the aorta, but no circumflex coronary artery (CX) was found in its typical place. On further inspection we found that the unknown vessel originating from the RPA was the CX. The CX was dissected from the RPA with a generous cuff

Address for correspondence: Radosław Jaworski, MD, Cardiac Surgery Department, Pomerian Center of Traumatology, Gdansk, Nowe Ogrody 1-6, 80-803 Gdańsk, Polska, tel. +48602243114, e-mail: radicis@go2.pl 
so that enough tissue would remain to allow the reimplantation (Fig. 1). The diameter of the CX was small enough not to allow cardioplegic solution into it. Then the Norwood procedure was performed in the usual manner using a cryopreserved pulmonary homograft patch with a period of selective brain perfusion. The CX was reimplanted into the posterior wall of the neoaorta using $8.0 \mathrm{~mm}$ nonabsorbable suture (Fig. 2). After cross clamp removal spontaneous sinus rhythm occurred. During rewarming the pulmonary arteries were anastomosed using a Gore-Tex ${ }^{\circledR}$ tube on a cryopreserved pericardium patch with the right ventricle. After full rewarming the operation was finished with the sternum left opened and significant inotropic support (adrenaline, dopamine, milrinone). The first postoperative hours were uneventful with reduction of inotropic support. At 36 hours after the operation there was attempt of sternum closure, but the acidosis increased, the child required increasing inotropic support and after 8 hours the sternum was reopened. In control echocardiographic examination there was low heart contractility with massive tricuspid valve insufficiency. Unfortunately the child required high doses of inotropic support and on the $5^{\text {th }}$ postoperative day died because of myocardial failure.

\section{Discussion}

Coronary artery anomalies are very rare in HLHS children and most often affect the left coronary artery. There is evidence that the incidence of coronary abnormalities is greater in patients with mitral hypoplasia and aortic atresia but there is no apparent difference in perfusion of the right ventricle among anatomic subgroups of coronary artery anomalies of hearts with hypoplastic left heart syndrome [2].

The coronary artery anomalies most often described in the literature concern the left coronary artery originating

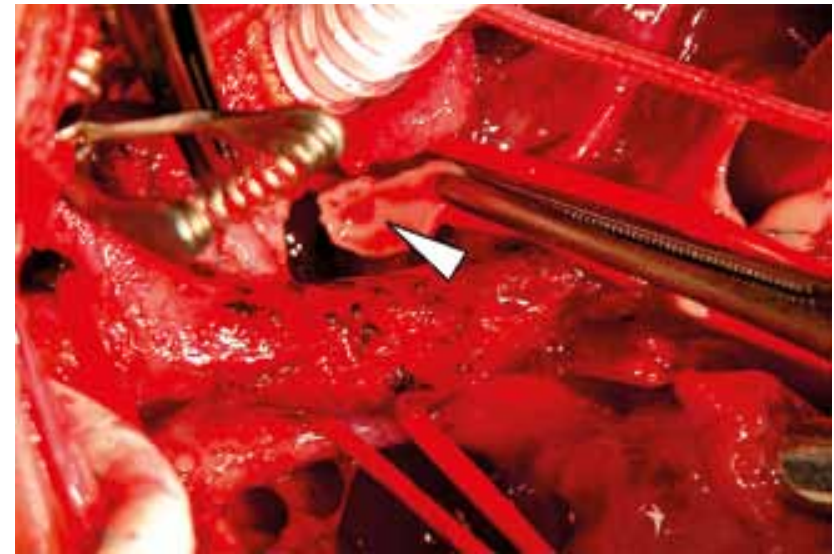

Fig. 1. Circumflex coronary artery dissected from right pulmonary artery with a cuff during Norwood procedure (arrow; operator view)

from the pulmonary artery [1, 3-6] but there is also one case report describing the right coronary artery originating from the RPA [7], as well as a single coronary artery originating from the pulmonary artery [8]. In the literature search we found only three reports describing coronary artery anomalies in 4 HLHS children where CX originates from the RPA: two cases diagnosed during the operation and another two during autopsy examination $[1,9,10]$. None of the patients with the described anomaly survived 24 hours after the operation. Unfortunately our patient died on the $5^{\text {th }}$ postoperative day because of myocardial failure.

Because routine use of angiographic examination is not part of standard preoperative assessment before the Norwood procedure, detailed coronary artery assessment as part of the routine echocardiographic evaluation of HLHS before surgery is crucial $[6,7]$. Nevertheless, intraoperative inspection of the coronary arteries should be performed routinely in all patients undergoing the Norwood operation
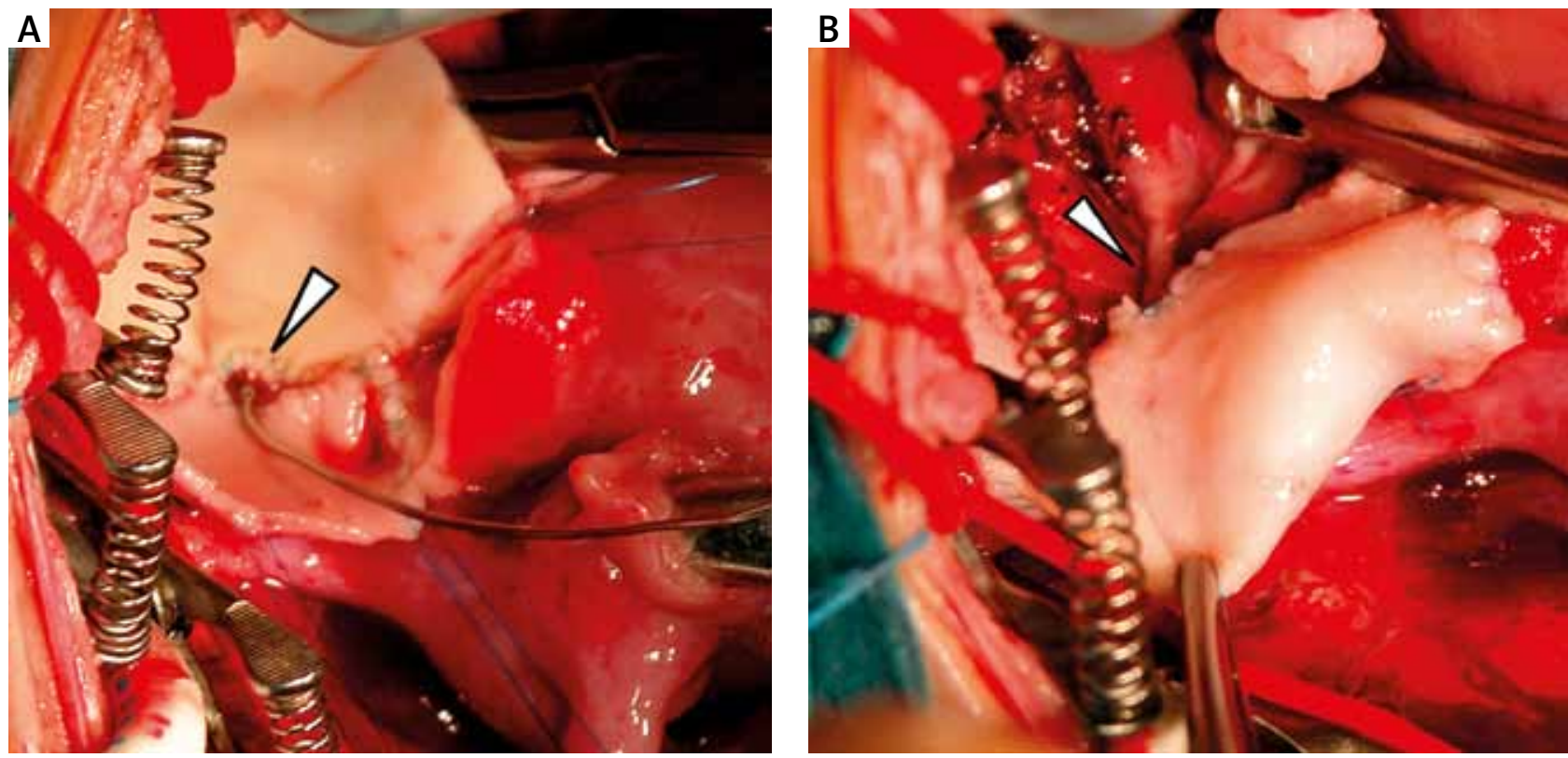

Fig. 2. Circumflex coronary artery (arrows) after reimplantation into the posterior wall of the neoaorta (operator views): A) from neoaorta lumen; B) after neoaorta reconstruction 
[7]. If the origin of the anomalous artery is on the main pulmonary artery it may not need reimplantation. However, direct aortic reimplantation seems to be the method of choice when the anomalous coronary artery originates from the pulmonary artery branches [4, 7].

Treatment of HLHS remains a challenge of present cardiosurgical congenital heart disease strategies. The operating surgeon encounters difficulties during Norwood procedures. That is why the proper tissue preparation with awareness of the possibility of coronary artery anomalies which can significantly influence the procedure course as well as the final result of the stage I palliation procedure in HLHS children is so important.

\section{References}

1. Nathan M, Emani S, Marx G, Pigula F. Anomalous left coronary artery arising from the pulmonary artery in hypoplastic left hearts: Case series and review of literature. J Thorac Cardiovasc Surg 2011; 142: 225-227.

2. Baffa JM, Chen SL, Guttenberg ME, Norwood W, Weinberg PM. Coronary artery abnormalities and right ventricular histology in hypoplastic left heart syndrome. J Am Coll Cardiol 1992; 20: 350-358.
3. Sarris GE, Drummond-Webb JJ, Ebeid MR, Latson LA, Mee RB. Anomalous origin of left coronary from right pulmonary artery in hypoplastic left heart syndrome. Ann Thorac Surg 1997; 64: 836-838.

4. Malec E, Mroczek T, Pajak J, Zajac A, Kolcz J, Januszewska K. Hypoplastic left heart syndrome with an anomalous origin of the left coronary artery. Ann Thorac Surg 2001; 72: 2129-2130.

5. Nosal' M, Omeje IC, Poruban R. Hypoplastic left heart syndrome with anomalous origin of left coronary artery from the right pulmonary artery: successful surgical treatment in a neonate. Eur J Cardiothorac Surg 2005; 28: 497-498.

6. Saroli T, Gelehrter S, Gomez-Fifer CA, van der Velde ME, Bove EL, Ensing GJ. Anomalies of left coronary artery origin affecting surgical repair of hypoplastic left heart syndrome and Shone complex. Echocardiography 2008; 25: 727-731.

7. Cleuziou J, Haas F, Schreiber C, Mössinger HJ, Lange R. Hypoplastic left heart syndrome with anomalous origin of the right coronary artery. Ann Thorac Surg 2006; 81: 341-343.

8. Ito T, Niino M, Ishikawa J, Matsumoto S, Matsuura T, Aoi T, Mukaida T, Matsuda $\mathrm{H}$, Ando $M$. Hypoplastic left heart syndrome with a single coronary artery originating from the pulmonary artery. Acta Paediatr Jpn 1995; 37: 61-63.

9. Villa E, Brancaccio G, Carotti A, Francalanci P, Di Donato RM. Circumflex coronary artery from right pulmonary artery in hypoplastic left heart syndrome. Ann Thorac Surg 2005; 80: 1919-1920.

10. Bartram U, Grunenfelder J, Van Paagh R. Causes of death after the modified Norwood procedure: a study of 122 postmortem cases. Ann Thorac Surg 1997; 64: 1795-1802. 